\title{
STATUS GIZI DAN HUBUNGANNYA DENGAN TINGKAT PRESTASI BELAJAR PESERTA DIDIK KELAS X DI SMKN 2 INDRAMAYU
}

\author{
Fauzan Effendy \\ Sekolah Tinggi Keguruan dan IImu Pendidikan \\ Nahdlatul Ulama Indramayu \\ E-mail: fauzan.effendy@yahoo.com
}

Diterima: 9 September 2017; Lolos: 2 November 2017; Dipublikasikan: 3 November 2017

Abstrak

Riset ini bertujuan untuk mengetahui relasi antara status gizi dengan tingkat prestasi belajar peserta didik kelas $X$ SMK N 2 Indramayu. Riset ini menggunakan metode kuantitatif dengan jenis analitik survei menggunakancrossectional approach. Teknik sampel menggunakan teknik simple random sampling, dengan jumlah sampel sebanyak 102 peserta didik kelas $X$ di SMK N2 Indramayu. Hasil riset menunjukkan tidak ada relasi yang kuat antara status gizi dengan tingkat prestasi belajar peserta didik di kelas $\mathrm{X}$ SMK N 2 Indramayu. Dengan hasil perhitungan didapat nilai koefisien korelasi $\left(r_{x y}\right)$ dengan besaran $0,125<\mathrm{r}$ tabel $(0,195)$.

Kata kunci: Status gizi dan prestasi belajar.

\section{NUTRITION STATUS AND THE RELATION WITH LEVEL OF STUDENTS CLASS X LEARNING RESULTS ON SMK NEGERI 2 INDRAMAYU}

\begin{abstract}
This research conducted toknow the relation between nutrition status and learning results on class $X$ students at SMK Negeri 2 Indramayu. This research is a quantitative research wich is a kind of analytyc survey with crosssectional approach.Technique of sampling that used in this research is simple random sampling. The subject, population, and sample of this research were all students of class Xof SMK Negeri 2 Indramayu wich count are 102 students. The results showed that no strong relations between nutrition status and learning results on class $X$ students at SMK Negeri 2 Indramayu. From that result got the value of coeficient $\left(r_{x y}\right)$ is $(0,125)<r_{\text {tabel }}(0,195)$.
\end{abstract}

Keyword: nutrition status and learning results.

\section{PENDAHULUAN}

Pembangunan nasional belakangan menitikberatkan kepada pembangunan dari aspek ekonomi serta peningkatan Sumber Daya

Email : fauzan.effendy@yahoo.com

No Handphone : 087715466000
(C) 2017 UN PGRI Kediri

p-ISSN: 2548-7833

e-ISSN: 2477-3379 
Status Gizi Dan Hubungannya Dengan Tingkat Prestasi Belajar Peserta Didik Kelas X Di Smk N2 Indramayu

Manusia (SDM) dari segi kualitas.Tujuan dari hal tersebut diatas adalah dalam rangka menghasilkan sumber daya manusia (SDM) yang sehat, cerdas, produktif dan mandiri, serta memiliki kualitas. Adanya peningkatan status gizi masyarakatadalahdasar untukmembentuk SDM yang memiliki kualitas. Oleh karena itu,dipantaunyapola konsumsi masyarakat, serta rutin mengukur status gizi masyarakat penting dilaksanakan agar besaran masalah yang ditemukan, bisa diatasi dengan segera. Organisasi Kesehatan Dunia (WHO) menyatakan bahwa gizi adalah pilar utama kesehatan, serta kesejahteraan selama siklus kehidupan berlangsung (Soekirman, 2002).

Gizi dinilai baik jika pertumbuhan fisik dan perkembangan mental seimbang dan serasi (Almatsier: 2003). Gizi dinilai kurang apabila terdapat kekurangan satu atau lebih zat gizi essential pada tubuh yang berakibat terjadinya gangguan dalam belajar (learning disabilities), menurunnya kemampuan kerja, sakit sampai yang paling fatal adalah menyebabkan terjadinya kematian. Nilai status gizi seseorang dipengaruhi oleh dua faktor, yaitu faktor dari luar: tingkat pendapatan, pendidikan, pekerjaan, dan budaya dan faktor dari dalam (internal): keturunan, asupan nutrisi, dan lain sebagainya.

Kekurangan gizi yang disebabkan oleh kemiskinan, ditunjukkan dengan taraf ekonomi masyarakat yang berpengaruh terhadap daya beli, intinya adalah pola konsumsi masyarakat tergantung oleh besaran pendapatan yang dihasilkan. Sedang yang memiliki impact pada penghasilan adalah jenis pekerjaan masyarakat itu sendiri. Tingkat pendidikan dan budaya masyarakatpun mempengaruhi masyarakat dalam hal penentuan kadar dan macam bahan pangan yang disediakan, bagaimana pangan tersebut diolah (dimasak), distribusi pangannya, serta kebiasaan konsumsi pangan orang perorang.

Cukupnya asupan gizi adalah pra-syarat dominan dalam hal tumbuh kembang masyarakat, tanpa terkecuali dalam hal tumbuh kembang otak. Asupan nutrisi yang mencukupi serta memenuhi kebutuhan tubuh, adalah determine pokok terhadap tumbuh kembang 
otak semenjak ada didalam kandung, pertumbuhan otak dimulai sejak ada didalam kandung sampai umur 0-5 tahun. Setelah itu, proses pertumbuhan otak akan melambat. Kemudian berkembangnya kemampuan otak dimulai saat umur 6 tahun sampai dengan menginjak dewasa. Oleh karena itu, sangat penting untuk memanfaatkan waktu pertumbuhan otak yang tidak lama tersebut dengan memberi asupan nutrisi secara baik, benar, dan rutin. Kecerdasan adalah salah satu dari empat faktor internal yang mempengaruhi hasil belajar. Tiga faktor yang lain antara lain: (1) bakat, kemampuan yang sudah dimiliki manusia sebagai kecakapan diri, (2) minat, kecenderungan untuk memperhatikan satu atau lebihaktivitas, dan (3) motivasi belajar, suatusituasi yang mendorong seseorang untuk belajar.

Prestasi belajar tidak bisa lepas dari aktivitas belajar, sebab aktivitas belajar adalah sebuah proses yang menghasilkan output prestasi belajar sebagai hasil dari aktivitas pembelajaran. Prestasi belajar ditentukan oleh tiga indikator, antara lain: ada perubahan kompetensi seseorang baik dari aspek kognitif, afektif, serta psikomotor peserta didik. Oleh karena, prestasi belajar adalah output penilaian peserta didik berdasar pada aspek kognitif, afektif, serta psikomotor selama mengikuti pembelajaran yang diukur dengan instrumen tes yang relevan, diketahui dengan nama Ujian Tengah Semester (UTS) dan Ujian Akhir Semester (UAS). Tujuan diadakannya tes tersebut adalah untuk mengetahui sejauh mana keberhasilan peserta didik selama melaksanakan pembelajaran, bisa dipergunakan pengajar untuk mengambil keputusan yang tertuang dalam buku laporan peserta didik.

Kemampuan kognitif erat hubungannya dengan status gizi seseorang (Hardinsyah, 2007).Kekurangan gizi bisa berakibat pada terganggunya motivasi belajar anak, kemampuanberkonsentrasi, serta kesanggupan dalam belajar. Hal-hal itu dapatberdampak pada hasil belajar anak (Berg, 1986). Status gizi dapatberpengaruh padalevel kecerdasan serta kemampuan menangkap pembelajaran, jadi, peserta didik yang punya nilai status gizi yang baik mempunyai daya tangkap yang 
Status Gizi Dan Hubungannya Dengan Tingkat Prestasi Belajar Peserta Didik Kelas X Di Smk N2 Indramayu

lebih baik dibandingkan dengan peserta didik yang memiliki status gizi kurang, sehingga berdampak pada hasil belajar yang didapat. Demi menghasilkan generasi sehat nan cerdas dimulai semenjak anak dalam kandungan sampai remaja, segala intervensi diberikan kepada anak wabil-khusus dalam hal pendidikan, kesehatan, serta gizi (Khomsan, 2004).

Makanan memberi pengaruh langsung terhadap perkembangan otak, makanan yang tidak cukup terkandung zat gizi yang diperlukan, sementara situasi ini berlangsung dalam jangka lama, dapat mengakibatkan perubahan proses metabolisme otak, sehingga menyebabkan ketidakmampuan otak untuk berfungsi secara normal. Dalamsituasi yanglebih fatal, kurangnya nilai gizi bisa berakibat terganggunya pertumbuhan pada tubuh, tubuh menjadi lebih kecil serta diikuti dengan ukuran otak yang kecil. Sehingga, jumlah sel-sel dalam otak menjadi berkurang menyebabkan terjadinya ketidakmatangan serta ketidaksempurnaan organisasi biokimia yang ada pada otak. Situasi ini mempengaruhi perkembangan level kecerdasan anak. Masalah gizi yang melanda di Indonesia sangat banyak dialami di daerah-daerah, masalah gizi tersebutadalah: Gangguan Akibat Kekurangan Yodium (GAKY) yang sangat mempengaruhi konsentrasi dan kemampuan belajar peserta didik, Kekurangan Energi Protein (KEP), Anemia, serta KurangVitamin A (KVA)(Soekirman, 2002). Berangkat dari dua hasil riset yang saling bertolak belakang. Pertama hasil riset Siti Maryam (2001) dengan judul Hubungan Status Gizi, Aktivitas Harian, dan Peer-Group dengan Prestasi Belajar Remaja, dengan hasil terdapat hubungan antara variabel status gizi dengan prestasi belajar. Namun, berdasarkan penelitian dari Jumirah, dkk (2003) dengan judul Kecukupan dan Status Gizi Siswa SMA serta Hubungannnya dengan Indeks Prestasi, dengan hasil bahwa tidak ada hubungan antara status gizi dengan tingkat prestasi belajar. Maka penelitian tentang status gizi dan hubungannya dengan tingkat prestasi belajar peserta didik perlu dilaksanakan kembali dalam riset ini. 


\section{METODE PENELITIAN}

Penelitian ini adalah penelitian metode kuantitatif dengan jenis analitik survei yang menggunakan cross sectional approach, bertujuan untuk mengetahui adanya relasi antara status gizi (variabel independen) dan prestasi belajar (variabel dependen), subjek yang dipakai dalam riset ini adalah peserta didik kelas $X$ di lingkungan SMK N 2 Indramayu. Menggunakan program Nutrisurvey 2005 Indonesian Versions sebagai alat ukur untuk menghitung status gizi. Lokasi penelitian berada di lingkungan SMK N 2 Indramayu. Penentuan subjek dan lokasi penelitian didasarkan atas pertimbangan bahwa di SMK $\mathrm{N} 2$ Indramayu belum pernah diteliti dengan tema yang peneliti susun. Waktu penelitian (pengambilan dan pengolahan data) dilaksanakan pada bulan Maret-April 2012.

Populasi adalah keseluruhan subjek penelitian (Arikunto, 1998). Berangkat dari definisi tersebut disimpulkan bahwa populasi merupakan keseluruhan jumlah subjek yang diteliti untuk digunakan selama riset berlangsung. Populasi dalam riset ini adalah seluruh peserta didik kelas $X$ di lingkungan SMKN 2 Indramayu sejumlah 400 peserta didik yang terbagi dalam 6 program kejuruan, antara lain: JB (Jasa Boga), NKPI (Nautika Kapal Penangkap Ikan), RPL (Rekayasa Perangkat Lunak), TAB (Teknik Alat Berat), TKJ (Teknik Komputer dan Jaringan), TPHP (Teknik Pengolahan Hasil Perikanan). Sampel merupakan sebagian dari populasi yang diteliti (Arikunto, 1998: 117). Tidak ada satu ketentuan absolut dalam menetukan besaran sampel untuk riset, yang penting adalah persen suatu sampel mesti bersumber dari populasi yang sudah ditentukan peneliti. Agar memperoleh sampel yang bisa merepresentasikan dari jumlah populasi, maka dipakai rumus Sovlin untuk menentukan besaran sampel yang digunakan, sebagai berikut:

$$
\mathrm{n}=\frac{\mathrm{N}}{1+\mathrm{Ne}^{2}}
$$

Ket:

$$
\begin{aligned}
\mathrm{n} & =\text { satuan sampel } \\
\mathrm{N} & =\text { satuan populasi }
\end{aligned}
$$


Status Gizi Dan Hubungannya Dengan Tingkat Prestasi Belajar Peserta Didik Kelas X Di Smk N2 Indramayu

$$
\text { e } \quad \text { prosentase ketidaktelitian }
$$

Denganbesaran populasi yang terdiri dari seluruh peserta didik kelas $X$ di lingkungan SMK N 2 Indramayu sejumlah 400 peserta didik, dan prosentase means error sebesar $10 \%$, maka diperoleh jumlah sampel sebagai berikut:

$$
\mathrm{n}=\frac{400}{1+400(0.1)^{2}}=99,7=100 \text { orang }
$$

Agar bisa memenuhi syarat untuk uji korelasi Pearson Product Moment dengan menggunakan rumus $\mathrm{n}+2$, maka total sampel menjadi 102 orang. Dikarenakan ada 6 program kejuruan, kemudian total sampel diolah menggunakan rumus berikut:

$$
\mathrm{ni}=\frac{\mathrm{Ni} \mathrm{n}}{\mathrm{N}}
$$

Ket:

$$
\begin{aligned}
\text { ni } & =\text { besaran sampel setiap kelas } \\
\mathrm{n} & =\text { besaran sampel seluruhnya } \\
\mathrm{N} & =\text { poulasi } \\
\mathrm{Ni} & =\text { jumlahpopulasi satu kelas }
\end{aligned}
$$

Dari 400 total populasi yang dibagi dalam 6 program kejuruan dengan jumlah peserta didik setiap programnya mencapai 67 peserta didik/kelas, maka didapatkan hasil sebagai berikut:

$$
\mathrm{ni}=\frac{67.102}{400}=17 \text { peserta didik/kelas }
$$

Hasil perhitungan mendapatkan hasil bahwa jumlah sampel masing-masing program kejuruan sejumlah 17 peserta didik yang akan digunakan sebagai sampel dalam riset ini. Teknik pengambilan sampelmenggunakan prosedur Random Sampling yang merupakan proses dimana semua jumlah populasi memiliki peluang yang sama untuk dijadikan sampel. Untuk metode yang dipakai menggunakan metode Simple Random Sampling, atau cara memilih sampel menggunakan sistem undian.

Variabel yang digunakan pada riset ini ada status gizi (variabel bebas), serta prestasi belajar (variabel terikat).Instrumen yang dipakai dalam riset ini ada dua macam yaitu, instrumen untuk mengukur status 
gizi, diantaranya: 1) Pengukur berat badan yang sudah diuji tera di balai metrologi Cirebon, dengan level ketelitian sebesar 0.5 kg; 2) Pengukur tinggi badan memakai stadiometer dengan level ketelitian $0.1 \mathrm{~cm}$; 3) Formulir hasil pengukuran tinggi dan berat badan yang seterusnya diolah memakai program aplikasi komputer Nutrisurvey untuk mengetahui status gizi peserta didik. Nutrisurvey merupakan sebuah program aplikasi berbasis komputer untuk menentukan tingkat status gizi berdasarkan umur, BB, dan TB. Instrumen mengukur prestasi belajar, antara lain: 1) Melihat rerata nilai ulangan peserta didik; 2) Melihat rerata nilai pada buku laporan peserta didik. Data responden dilakukan dengan melihat daftar absen peserta didik dan biodata peserta didik yang didapat dari wali kelas masing-masing.

Teknik analisis data yang digunakan adalah: 1) Analisis data deskriptif, untuk mengetahui frekuensi, prosentase, rerata, serta standar deviasi dari seluruh data, meliputi angka status gizi dan tingkat prestasi belajar peserta didik; 2) Analisis data dilakukan dengan menggunakan program SPSS. Menghitung uji normalitas data dalam penelitian ini dilakukan uji Kolmogorov-Smirnov bila perolehan data normal dilanjutkan dengan uji korelasi Pearson Product Moment.

\section{HASIL PENELITIAN DAN PEMBAHASAN}

Dalam penelitian ini terdapat dua variabel yaitu, status gizi (variabel bebas) dan prestasi belajar (variabel terikat). Hasil analisis data masingmasing variabel dapat disimak dari deskripsi berikut:

\section{Status Gizi (X)}

Deskripsi hasil penelitian tingkat status gizi disajikan pada tabel 1 dan gambar 1 dibawah ini:

Tabel 1. Deskripsi Hasil Penelitian Status Gizi

\begin{tabular}{|c|c|c|c|}
\hline Interval & Kategori IMT Nutrisurvey 2005 & $\mathbf{F}$ & $\%$ \\
\hline$<19$ & Kurus & 51 & 50,00 \\
\hline $19-24$ & Normal & 44 & 43,14 \\
\hline \multirow[t]{2}{*}{$>24$} & Overweight & 7 & 6,86 \\
\hline & Jumlah & 102 & 100 \\
\hline
\end{tabular}




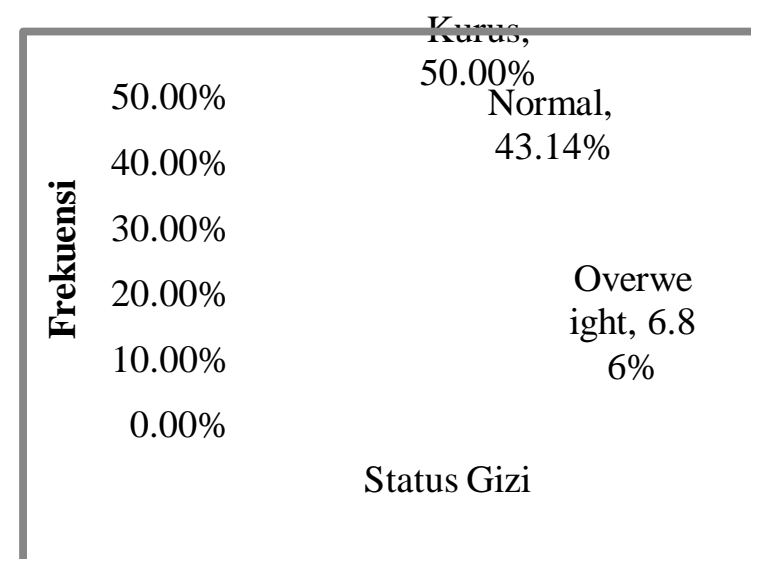

Gambar 1. Status Gizi Dalam Grafik

Hasil perhitungan diatas menunjukkan bahwa tingkat status gizi peserta didik kelas X SMK N 2 Indramayu adalah sebagai berikut: 1) Kategori kurus berjumlah 51 peserta didik (50\%); 2) kategori normal berjumlah 44 peserta didik (43,14\%)dan; 3) kategori overweight( gemuk) berjumlah 7 peserta didik (6,68\%).

\section{Prestasi Belajar (Y)}

Deskripsi hasil penelitian tingkat prestasi belajar disajikan pada tabel 2 dan gambar 2 dibawah ini:

Tabel 2. Deskripsi Hasil Penelitian Prestasi Belajar

\begin{tabular}{|c|c|c|c|}
\hline Interval & $\begin{array}{c}\text { Kategori (Buku Laporan Pendidikan } \\
\text { 2012) }\end{array}$ & $\mathbf{F}$ & $\%$ \\
\hline$<75$ & Buruk & 38 & 37,25 \\
\hline$>=75$ & Baik & 64 & 62,75 \\
\hline \multicolumn{2}{|r|}{ Jumlah } & 102 & 100 \\
\hline
\end{tabular}




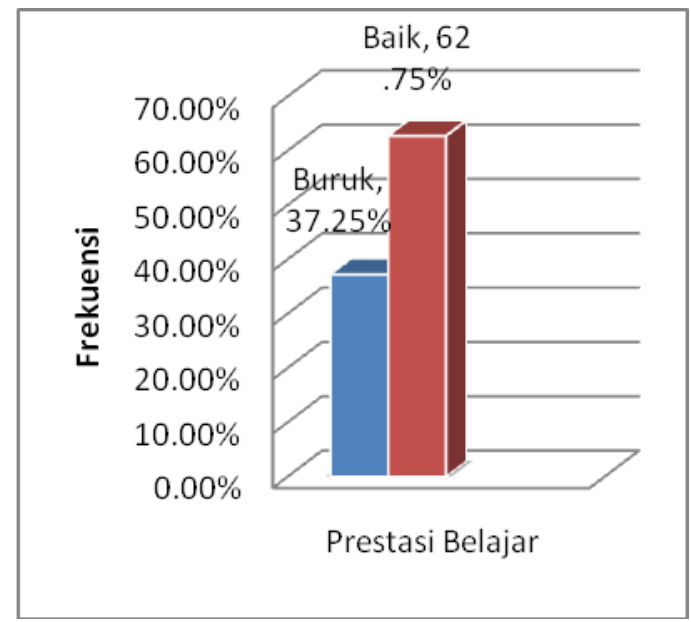

Gambar 2. Prestasi Belajar Dalam Grafik

Hasil perhitungan diatas menunjukkan bahwa tingkat prestasi belajar peserta didik kelas X SMK N 2 Indramayu adalah sebagai berikut: 1) Kategori buruk berjumlah 38 peserta didik (37,25\%) dan; 2) kategori baik sebanyak 64 peserta didik (62,75\%).

\section{Analisis Data}

Analisis data berguna untuk mengetahui ada dan tidaknya korelasi antara status gizi dengan prestasi belajar.Sebelum itu diperlukan uji prasyarat yang harus ditempuh agar hasil olah data bisa dipertanggungjawabkan. Uji prasyarat tersebut meliputi uji normalitas dan uji linearitas. Dideskripsikan pada sajian berikut ini:

\section{Uji Normalitas}

Menggunakan bantuan program SPSS 18.0 dengan rumus Kolmogorov-Smirnov. Dengan asumsi normal atau tidaknya sebuah data adalah jika $\mathrm{p}>0,05$ (prosentasi ketidaktelitian $5 \%$ data dinyatakan normal, jika $\mathrm{p}<0,05$ (5\%) data dinyatakan tidak normal. Hasil uji normalitas disajikan pada tabel 3berikut:

Tabel 3. Hasil Uji Normalitas

\begin{tabular}{llll}
\hline Variabel & p & Sig 5\% & Keterangan \\
\hline Status Gizi $(\mathrm{X})$ & 0,137 & 0,05 & Normal \\
\hline Prestasi Belajar $(\mathrm{Y})$ & 0,570 & 0,05 & Normal \\
\hline
\end{tabular}


Diketahui bahwa nilai probabilitas ada di angka 0.137 , yang mana 0.137>0.05 bisa disimpulkan bahwa data status gizi memiliki distribusi normal, sedangkan data prestasi belajar nilai probabilitasnya sebesar 0.570, yang mana $0.570>0.05$ jadi, data prestasi belajar memiliki distribusi normal.

\section{Uji Linieritas}

Uji linearitas dilakukan untuk mendeskripsikan hubungan antar variabel (bebas dan terikat) linear atau tidak. Kriteria yang dipakai adalah dengan asumsi jika nilai $p>0,05$ (prosentase ketidaktelitian $5 \%$ ) bisa dinyatakan bahwa hubungan antar variabel adalah linear. Sedangkan, jika nilai $p<0,05$ (5 \%) dinyatakan hubungan antarvariabel tidak linear. Berdasar pada perhitungan uji linearitas didapat nilai $p$ sebesar 0.218. Dapat disimpulkan bahwa hubungan variabel $X$ (status gizi) dengan variabel $Y$ (prestasi belajar) sebesar $p$ 0,218 > 0,05 yang berarti kedua variabel tersebut linear.

\section{Uji Hipotesis}

Uji hipotesis yang digunakan adalah uji korelasi Pearson Product Moment dan dihitung menggunakan program SPSS versi 18.0.Asumsi yang digunakan untuk mengetahui hubungan antara dua variabel adalah jika $r_{\text {hitung }}>r_{\text {tabel }}(0.195)$ dinyatakan ada hubungan antara dua variabel terkait, namun jika angka menunjukkan sebaliknya maka tidak ada hubungan. Hasil uji korelasi bisa disimakdalam tabel 4 berikut:

Tabel 4. Hasil Uji Korelasi Pearson Product Moment

\begin{tabular}{lcccc}
\hline \multicolumn{1}{c}{ Hubungan } & $\mathbf{N}$ & $\mathbf{r}$ Tabel & $\begin{array}{c}\text { Koefisien } \\
\text { Korelasi } \\
\left(\mathrm{r}_{\mathrm{xy}}\right)\end{array}$ & $\begin{array}{c}\text { Koefisien Sig } \\
\left(\mathbf{r}^{2}\right)\end{array}$ \\
\hline $\begin{array}{l}\text { Status Gizi-Prestasi } \\
\text { Belajar }\end{array}$ & 102 & 0,195 & 0,125 & 0,211 \\
\hline
\end{tabular}

Hasil perhitungan menunjukkan bahwa nilai koefisien korelasi $\left(r_{x y}\right)$ sebesar 0,125 $>r$ tabel $(0,195)$. Kesimpulannya, $H_{0}$ diterima, $H_{1}$ ditolak, jadi tidak ada hubungan yang kuat antara tingkat status gizi dan 
prestasi belajar peserta didik kelas X SMK N 2 Indramayu. Angka uji signifikansi diperoleh nilai sebesar 0,211 >0,195 artinya secara asosiasi kedua variable tersebut adalah signifikan.

Status gizi merupakan determine utama dalam pertumbuhan otak, yang berarti bahwa status gizi memiliki peranan penting dalam membentuk kecerdasan. Kekurangan atau kelebihan zat-zat esensi gizi bisa mempengaruhi terjadinya learning disabilities (gangguan belajar) yang dapat berpengaruh langsung terhadap kesuksesan prestasi belajar.Namun, jika dilihat dari hasil penelitian ini status gizi tidak berpengaruh terhadap prestasi belajar peserta didik. Dalam penelitian ini diduga ada faktor lain lebih mempengaruhi hasil belajar peserta didik. Faktor-faktor yang mempengaruhi proses dan hasil belajar peserta didik di sekolah, secara garis besar dapat dibagi kepada tiga bagian (Syah, 2008). Antara lain: 1) Faktor internal yaitu kondisi jasmani dan rohani peserta didik, yang dipengaruhi juga oleh beberapa sebab, diantaranya:(a) Faktor fisiologis, keadaan fisik yang sehat akan memberikan hasil belajar yang baik; (b) faktor psikologis, bisa mempengaruhi prestasi belajar adalah perhatian, minat, motivasi, dan bakat; 2) Faktor eksternal, kondisi lingkungan sekitar peserta didik seperti: kehidupan sosial, kondisi nonsosial, seperti keadaan dan letak gedung sekolah, keadaan dan letak rumah tempat tinggal keluarga, alat-alat dan sumber belajar, keadaan cuaca dan waktu belajar yang digunakan peserta didik. Faktor-faktor tersebut dipandang turut menentukan tingkat keberhasilan belajar peserta didik di sekolah, Faktor pendekatan belajar (learning approach), jenis upaya belajar peserta didik yang meliputi strategi dan metode yang digunakan peserta didik dalam mengikuti kegiatan pembelajaran.

Jadi, dalam penelitian ini menunjukkan bahwa semakin baik status gizi peserta didik belum tentu bisa mendapatkan nilai tinggi dalam hal prestasi belajar, begitu juga sebaliknya, semakin buruk status gizi peserta didik belum tentu mendapat nilai rendah. Artinya, status gizi tidak menjadi faktor penentu dalam keberhasilan peserta didik mendapat hasil prestasi belajar yang baik, dengan usia peserta didik yang memasuki tingkat 
remaja, diduga ada banyak faktor-faktor selain status gizi yang lebih kuat mempengaruhi prestasi belajar peserta didik seperti yang sudah dijelaskan sebelumnya. Hasil dari riset ini senada dengan hasil penelitian dari Jumirah, dkk (2003) dengan judul "Kecukupan dan Status Gizi Siswa SMU Dharma Pancasila Medan serta Kaitannya dengan Indeks Prestasi", yang menyatakan bahwa tidak ada hubungan antara status gizi dengan tingkat prestasi belajar.

\section{SIMPULAN}

Penelitian menyimpulan tidak terdapat hubungan kuat antara tingkat status gizi dan prestasi belajar peserta didik kelas X SMK N 2 Indramayu, dengan nilai koefiesien korelasi sebesar r 0.125 , maka $r 0.125$ $<r$ tabel (0.195). Hal ini diduga karena masalah status gizi pada peserta didik masih termasuk dalam tahap ringan sehingga tidak banyak berpengaruh terhadap proses dan hasil belajar peserta didik.

\section{SARAN}

Saran-saran dalam riset ini sebagai berikut: 1) Peserta didik yang masih mempunyai status gizi yang kurang, hendaknya berusaha meningkatkan status gizinya dengan melaksanakan pola makan sehat dan istirahat secara teratur agar tercipta kondisi badan yang sehat dan tahan terhadap penyakit; 2) Guru mampu menjadikan temuan ini untuk bahan kajian serta memberikan wawasan tentang ilmu gizi mengingat masih banyak peserta didik yang memiliki status gizi tidak normal; 3) Melakukan penelitian lanjutan dengan menambah variabel yang lain, sehingga variabel yang memengaruhi prestasi belajar dapat teridentifikasi lebih banyak lagi.

\section{DAFTAR PUSTAKA}

Almatsier, S. 2001. Prinsip Dasar Ilmu Gizi. Jakarta: PT. Gramedia Pustaka Utama.

Arikunto, S. 1998. Prosedur Penelitian Suatu Pendekatan Praktek. Jakarta: PT. Rineka Cipta. 
Berg A. 1986. Peranan Gizi dalam Pembangunan Nasional. Zahara DN, Penerjemah. Jakarta: CV Rajawali.

Hardinsyah. 2007. Inovasi Dan Pengembangan Modal Sosial Bagi Peningkatan Kualitas Hidup Manusia Dan Pengentasan Kemiskinan. Orasi Ilmiah, Fakultas Ekologi Manusia: Institut Pertanian Bogor.

Jumirah, Lubis, Z., Aritonang, E. 2003. Kecukupan dan Status Gizi Siswa SMU Dharma Pancasila Medan serta Kaitannya Dengan Indeks Prestasi. Departemen Gizi Kesehatan Masyarakat. FKM USU: Medan.

Siti, Maryam. 2001. Status Gizi, Peer Group, dan Aktivitas Harian serta Kaitannya dengan Prestasi Belajar Remaja (Studi Kasus Pada Dua SMA di kota Bogor). Tesis Pascasarjana yang tidak dipublikasi. IPB: Fateta IPB.

Soekirman.2002. IImu Gizi dan Aplikasinya. Jakarta: Dirjen Perguruan Tinggi Depdiknas.

Syah, M. 2008. Psikologi Pendidikan Dengan Pendekatan Baru. Bandung: Remaja Rosdakarya. 